\title{
Human Factors and Child's Safety: A Review of Charitable Children's Institutions in Kisumu Municipality, Kenya
}

\author{
John Okello Weda, Anne Wambui Mwangi \\ Department of Education and External studies, University of Nairobi, Nairobi, Kenya \\ Email address: \\ wedaokello@gmail.com (J. O. Weda), annemurathi@yahoo.com (A. W. Mwangi) \\ To cite this article: \\ John Okello Weda, Anne Wambui Mwangi. Human Factors and Child's Safety: A Review of Charitable Children's Institutions in Kisumu \\ Municipality, Kenya. Humanities and Social Sciences. Vol. 3, No. 1, 2015, pp. 47-56. doi: 10.11648/j.hss.20150301.16
}

\begin{abstract}
The purpose of this study was to investigate the influence human factors of Charitable Children's Institutions on child safety in Kisumu Municipality, Kenya. The objectives of this study were, to examine the extent to which staff competency and staff commitment in a charitable children's institution influence their safety, to assess how staff competencies in charitable children's institutions influence child safety. This study was conducted through descriptive survey design methodology. It employed stratified sampling, simple random sampling and purposive sampling techniques. The main tools for collecting data included questionnaires, and interview schedule. Data were analyzed using descriptive statistics and findings presented in tables. Key findings of the study indicate that Charitable Children's Institutions in Kisumu Municipality are able to provide the children with meals at least three times a day though some lack health and nutrition programs. Most have not fully embraced children's rights specifically on the right of participation. Their children have diminished opportunities for their psychosocial needs to be met and are not prepared to cope with disasters like fire. The majority of the children were happy with the services they receive from the staff who were widely experienced in their work. However professional staff in all areas of service is missing in these institutions. Some institutional policy statements that were meant to protect the wellbeing of the children were taken for granted by staff and management. Psychosocial needs of the children should be addressed by providing opportunities for quality interaction among the children and with professional children workers. Disaster preparedness plan that include practical drills with the children must be in place. Staffs must be adequate, competent and experienced.
\end{abstract}

Keywords: Human Factors, Charitable Children's Institutions, Kisumu Municipality

\section{Introduction}

The safety of children is a matter of great concern to the society and the entire nation. Death of parents or extreme poverty make children end up in Charitable Children's Institutions (CCIs). According to SOS (2007), children under 18 years of age who have lost the care of their parents and those who face a significant risk of this happening to them should be given the greatest focus. These include children who are living with a chronically-ill parent or children who have already lost one or both parents or are living in an orphan household. In particular, greatest attention is given to those children within this group who are living in the most vulnerable circumstances, such as those within child-headed and grandparent-headed households (SOS, 2007).

Child Abuse and neglect have existed all over the world and for many centuries. The bible tells about the Canaanites offering children to their God Baal. This is a form of child abuse. English poems and prose are full of situations in which children are abused and exploited. The most outstanding is Charles Dickens' depiction of Oliver Twist, who was so humiliated when he dared to ask for some more food (Dickens, 1838). In many cultures, deformed children were neglected and hidden away from the public view (Cox \& Marks, 2006). This practice still exists today. In some cultures, when a woman has twins and one child is a girl, the girl twin is neglected and may die. Every culture has some punishment for disciplining children, and you may be aware of the saying, "Spare the rod and spoil the child". Child abuse and neglect are outside the normal formal punishment (Stanfield and Bwibo, 2005).

In Nigeria, a rapid assessment of orphans and vulnerable children conducted in 2004 with UNICEF support revealed that there were about seven millions orphans in 2003 and that 800,000 more orphans were added during that same year. Out of this total number, about 1.8 million are orphaned by HIV/AIDS. With the spread of HIV/AIDS, the number of 
orphans is expected to increase rapidly to 8.2 million by 2010 .

In Egypt, the Mosques of Charity orphanage houses about 120 children in Giza, Menoufiya and Qalyubiya. (Amany, 1999)Dar Al-Iwaa provides free education and accommodation for over 200 girls and boys. Dar Al-Mu'assassa Al-Iwaa'iya Shelter Association houses about 44 children. There are also 192 children at The Awladi, 30 at SayedaZeinab orphanage, and 300 at My Children Orphanage. There are about 185 orphanages in Egypt. (Réhab, 2002)

In Ghana, a 2007 survey sponsored by OrphanAid Africa and carried out by the Department of Social Welfare came up with the figure of 4,800 children in institutional care in 148 orphanages. Of these at least four orphanages have since been closed. The Department of social services of Ghana has adapted a policy that institutions should be used only as a last resort (CRI, 2008). The situation in Ruanda and Tanzania reflects a situation where the majority of orphans and vulnerable children live in the community. In Ruanda, out of 400,000 orphans, 5,000 are living in orphanages.

Locally in Kenya, the origin of the Department of Children's Services now in the Ministry of Gender, Children and Social Development can be traced back to the Colonial era, when it existed as a Juvenile Correctional Institution. Its earliest correctional and rehabilitation institution, the then Kabete Approved School was built between 1910 and 1912, in the lower Kabete area. The school was founded to cater for youth who had been imprisoned for failing to register themselves or their inability to carry the identity card. With the reorganization and prior to the attainment of independence, the Approved Schools were up-graded into a fully-fledged Department under the repealed Children and Young Persons Act Cap 141. Initially, the Department was known as the Department of Approved Schools but after independence it became Children's Department hereby referred to as the Department of Children's Services (Government of Kenya, 2011).

\subsection{Problem Statement}

Addressing the needs of orphans and vulnerable children (OVC) in Charitable Children's Institutions and mitigating negative outcomes of the growing OVC population is a high priority for Kenya. International stakeholders recognize this as an issue with social, economic, and human rights dimensions. While some valuable research has been conducted on OVC in Kenya, significant gaps remain. There is knowledge gap as to whether the interventions in charitable children's institutions in Kenya are working the way they should. The lack of vital strategic information is hindering policy makers like the National Council of Children's Services and other program leaders from making well-informed decisions about the path forward (Biembaet al., 2009). Day in day out, there are increasing reported cases of crimes related to children. If the issue of safety in charitable children's institution is not addressed adequately, two things are most likely to happen. One, charitable children's institutions may fail in their duties and role to provide much needed services to the orphans and vulnerable children living in them and therefore not being a place of safety. This may lead to the other greater danger where the children living in these institutions may opt to go to the streets to seek for alternative live which more often than not ends up in more problems. With street children comes the danger of many social ills such as immorality, insecurity, drug abuse and addiction, low productivity, child labor, alcoholism, teenage pregnancy, suicide, early marriages and many others. On the other hand if charitable children's institutions fail in their duties of providing services and safety to the OVCs, there is likelihood that they may turn into centers where rights of children are abused and resources meant for the children misused. There is therefore a need to come up with a study to investigate how Charitable Children's Institutions influence child safety in Kisumu Municipality, Kenya.

\subsection{Objectives of the Study}

1. To assess the role of staff commitment in charitable children's institutions on child safety in Kisumu Municipality

2. To assess how staff competencies in charitable children's institutions influence child safety in Kisumu Municipality

\subsection{Research Questions}

1. How do service providers in charitable children's institutions influence child safety in Kisumu Municipality?

2. How do service providers in charitable children's institutions influence child safety in Kisumu Municipality?

\subsection{Significance of the Study}

It is hoped that the findings of this study will provide corrective actions and necessary information for charitable children's institutions to enhance child's safety in these institutions. The information generated from this study may be useful to key stakeholders such us donors, sponsors, beneficiaries, human rights activists, community members and the government among other stakeholders. It is also hoped that assembling the relevant available data on OVC in one place, and acknowledging the gaps that still exist in our knowledge, will assist policy makers and program implementers to make evidence-based decisions about how best to direct funding and program activities and maximize positive outcomes for children and their caretakers

\subsection{Conceptual Framework}

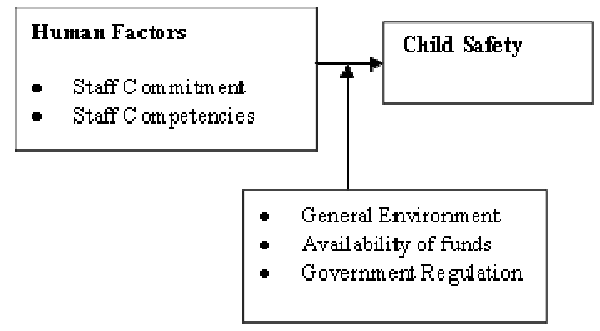

Figure 1. Conceptual Framework. 


\section{Literature Review}

\subsection{Staff Commitment}

Sultana (2012) defined commitment as a state of being where an individual is bound by his/her actions to sustain activities in which he/she is involved. There are three aspects of staff commitment.

The first aspect of staff commitment is affective commitment. Affective commitment refers to the emotional attachment that an employee has in an organization (Price, 2011). It is the extent at which employees appreciate to be members of an organization. According to Rhoades (2001), affectively committed employees are seen to have a sense of identification and belonging and this motivates them to increase their participation in the activities of an organization. Additionally, affective commitment makes employees to have willingness to meet the goals of an organization as well as the desire to stay in the organization. Beck and Wilson (2000) note that organizational members who have an affective level of commitment have a longing to remain in the organization because they view their values and goals to be congruent with those of the organization.

The second form is continuance commitment. Meyer and Allen (1997), cited by Lee (2010) define continuance commitment as the employee awareness of the costs that are related with departing the organization. This means that continuance commitment is the enthusiasm to remain in an organization due to the personal investments which cannot be transferred. Price (2011) argues that continuance commitment exists when an employee needs the benefits and the salary associated with remaining in an organization. Additionally, it may arise when employees feel that they cannot find another job or when they believe that they owe their success to the organization.

The third form of commitment is normative commitment. According to Meyer and Allen (1997), cited by Lee (2010) normative commitment is a feeling of obligation that an individual has to continue with the employment. It arises from an employee obligations and personal values that the person feels towards the organization. Coetzee (2005) emphasizes that employees' with a high level of normative commitment feel that they ought to remain with the organization. The feeling of obligation to stay in the organization may come about due to the internalization of normative pressures exercised on an employee before joining the organization (Muncherji and Dhar, 2011).

These aspects of staff commitment influence their performance in the organizations. In the Charitable Children's Institutions set up, these factors will influence the services offered by such institutions safety included.

\subsection{Staff Competencies}

The term "competency" refers to a combination of skills, attributes and behaviours that are directly related to successful performance on the job. Defining competencies is important both for the Organization and for staff. Competencies are forward-looking. They describe the skills and attributes staff and managers will need in order to build a new organizational culture and meet future challenges. They help organizations clarify expectations, define future development needs, and do more focused recruitment and development planning. Competencies provide a sound basis for consistent and objective performance standards by creating shared language about what is needed and expected in an Organization (UNEP, 2007).

Staffing of CCIs is a sensitive matter that entails determining what type of people will be required, recruiting prospective employees, selecting employees, setting performance standards, compensating employees, evaluating performance, counseling employees, training and developing employees (Dessler, 2008). The staff of CCIs needs to be adequate and competent for the job they are employed to do.

Children are potentially the most threatened members of society because they are among the most vulnerable. They are prey to physical, emotional, sexual and substance abuse. Some have learning difficulties, physical disabilities or mental health problems (UNEP, 2007). Often the unstable, disadvantaged child is regarded as a menace and should be disciplined. But to staff in CCIs he is damaged, perhaps depressed, frightened and lonely. It is their job to help him to organize care and support for the child who is at risk or who has special needs (Dessler, 2008).

The staff are based in CCIs where children with complex problems exist in circumstances in which their liberty or safety is threatened. Staffs at CCIs work for more than 56 hours per week and sometimes are forced to work with anti-social hours when a case demands it. Regular daily requirements include being with the children, attending meetings, emergencies to respond to, reports, records and letters to write, liaison with other professionals, planning and reviewing of procedures and progress. There may also be a need to attend juvenile court hearings. Staff may also get involved with special research projects on issues affecting a number of children (Dessler, 2008).

The staff would need to be able to engage with the child to identify their needs, respect the rights of the children and establish an effective way of talking to them. They also need to communicate with people from all walks of life, be good at interviewing, listening and observation. They also need to be able to deal with difficult situations and conflict. Other areas of competencies include how to negotiate and organize, how to deal, a good understanding of the principles of intervention, engaging with parents to effect change, have a stable and mature temperament and have report writing skills (Cole, 2004).

Recruitment and selection of staff in a CCI is a very important aspect of staffing. The aim of recruitment is to ensure that the organizations demand for employees is met by attracting potential employees in a cost effective and timely manner. The aim of selection is to identify, from those coming forward, the individuals most likely to fulfill the requirements of the organization. To put it in another way, recruitment is concerned with assembling the raw materials, and selection is 
concerned with producing the right blend for the organization, at a particular point in time (Cole, 2004).

\subsection{Theoretical Literature}

\subsubsection{Maslow's Need Hierarchy Theory}

The Maslow hierarchy of needs theory holds that individuals are motivated to satisfy their wants or needs (Coldrey, 2010). In this regard, Maslow suggested that motivation is based on five basic needs; physiological, safety, belonging, self-esteem and self-actualization. According to Singh (2007), at the bottom of Maslow's hierarchy are the physiological needs. These needs must be satisfied first followed by the safety needs. According to Maslow an individual must be essentially comfortable in one level before moving in an advanced position to meet higher needs (Jiang at el, 2009).

Organizations can help employees to meet their basic physiological needs by paying them reasonable wages (Coldrey, 2010). Jiang at el (2009), emphasizes that Maslow hierarchy of needs theory can assist organizations to reward performance based on the needs of the employees. Employees with self-esteem needs can be provided with non-financial rewards like recognition and praise for achieving the set performance levels. Therefore, Maslow's theory can help an organization to design its rewards and meet the expectations of its employees.

\subsubsection{Alderfer's ERG theory}

This theory holds that individuals have three types of needs; existence, relatedness and growth (Jiang at el, 2009). Singh (2007) observes that the three needs are arranged in an orderly form from existence needs to relatedness needs and finally to growth needs. Additionally, the ERG theory suggests that individuals may be having more than one need at the same time. According to Shields (2007), employees' higher level needs may act as motivators even if the lower level needs are not fully satisfied. This implies that an organization can use total rewards strategy in order to improve employees' commitment as well as to motivate them to increase their performance.

\subsubsection{Expectancy Theory}

According to Armstrong (2012), the expectancy theory suggests that individuals are motivated based on the estimates of how the anticipated results of a given behavior will lead to the planned performance. This implies that employees' motivation is centered on the Expectancy that effort will lead to an outcome. Jiang at el (2009) emphasizes that the Expectancy theory is focused on the ways in which organizational members make decisions on which specific actions to perform and the amount of effort to exert. Therefore, the Expectancy theory predicts the level of employees' motivation depending on the desirability of the rewards pursued and the likelihood of obtaining those rewards.

Coldrey (2010) notes that if employees recognize that they are going to get valued rewards from the organization, they are likely to be more motivated and put greater efforts to their jobs.
This indicates that motivation is likely only when employees can perceive a clear relationship between their performance and the expected rewards. Armstrong (2012) observes that the Expectancy theory has three dimensions; expectancy, instrumentality and valence. The degree of motivation in each dimension must be high in order to achieve employees preferred level of behavior.

\subsubsection{Adams Equity Theory}

The Equity theory argues that employees' satisfaction with rewards is associated with perceptions about the relationship between pay and the amount of effort put in the work as compared with rewards given to other employees (Armstrong and Murlis, 2007). This implies that employees have a desire to be treated fairly in their work place by ensuring that their inputs are rewarded appropriately and are related with rewards received by other employees in the same level. Coldrey (2010) observes that the Equity theory indicates that employees' satisfaction with pay is based on the difference between the rewards that they receive and their feelings on what they should be receiving.

According to Jiang at el (2009), the Equity theory assumes a balance of employees' inputs and outputs as compared to others. Employees tend to be unsatisfied once they perceive that they receive fewer rewards as compared to their inputs. Armstrong and Murlis (2007), state that the Equity theory holds that there should be a system of fair payment for any given level of work and those individuals are intuitively aware of their own efforts as well as the equitable level of rewards. Therefore, total rewards strategy should ensure that employees realize compensation that is fair and linked with their performance.

\section{Research Methodology}

\subsection{Research Design}

This study was conducted through descriptive survey design. The study was concerned with the influence of human factors in Children's Institutions on child safety in Kisumu Municipality, Kenya. It was specifically intended to investigate the relationship between the human factors in Charitable Children's Institutions and Child safety. This study adopted this design because it allows for rapid collection of date data.

The survey design generally presents oriented methodology and is used to investigate populations by selecting samples to analyze and discover occurrences. It is used to provide quantitative and numeric descriptions of some part of the population and to describe and explain (Osoo and Onen, 2005). Survey design also considers issues such as economy of the design, rapid data collection and ability to understand population from a part of it. For the purpose of this study, the survey design was cost effective, efficient and flexible enough. It also minimized bias and maximized reliability of the data collected. This design also yielded maximum information and provided an opportunity for considering many different aspects of the problem (Kothari, 2004). 


\subsection{Target Population}

This study was conducted in Kisumu Municipality. Kisumu Municipality was chosen because it had a high concentration of CCIs thus ensuring a cost effective and time saving process. The poverty levels and HIV prevalence in Kisumu Municipality is also high thus leading to high numbers of OVCs. The target population consists of all the managers of 17 registered CCIs. In these institutions, there are a total of 340 children and one children's officer.

\subsection{Sample Size and Sample Selection}

A sample is a small part of a large population which is thought to be representative of the larger population (Prewitt, 1975). The sample was carefully selected to ensure representativeness of the population. In this study, all the managers of the 17 registered CCIs were used in the study. All the managers of the CCIs took part in the study because the number of the managers was small enough and did not require. In Kisumu Municipality, there are about 340 children living in CCIs. Therefore according to the Morgan Table 169 children were sampled using simple random sample technique. The children's officer from the children's department was also purposively selected.

\subsection{Research Instruments}

This study employed the use of questionnaires and interview schedule, as the main tools for collecting primary data. These tools were selected because of the nature of data to be collected, the time available and the objectives of the study. The overall aim of this study is to study the influence of charitable children's institutions on child safety in Kisumu Municipality. The study was mainly concerned with the observations, views, opinions, perceptions, feelings and attitude. Such information was best collected through the use of interviews and questionnaires (Osoo and onen, 2005). The researcher used semi-structured instruments and open ended interview schedule. This enabled the researcher to balance between the quantity and quality of data collected. This delicate balance between quality and quantity of information is useful for a fuller explanation of the phenomenon under investigation (Peter, 1994). Pilot testing is a very important aspect in any study. In this study, the research instruments were tested in one charitable children's institution. The participants of the pilot testing were not eligible to participate in the main study. The effects of extraneous variables was reduced or controlled by randomization. Similarly, reliability was ensured by using test-retest technique to a given Charitable Children's Institution.

\subsection{Data Collection Procedures}

Data was collected using observation checklists, questionnaires, and interviews schedule. These tools were used to collect primary data from the participants while secondary data was collected from books, journals, newspapers and the internet. Five research assistants were then trained on how to use these tools for collection of the required data. They did data collection, data compilation and data cleaning on a daily basis during the data collection exercise to ensure data integrity (Sapsford, 2007). The instruments to be used for collecting data had six sections. The first section for the child beneficiary questionnaire had demographic information consisting of gender, age, class, religion, school and number of siblings. The interview schedules for the managers of CCIs and the children's officer had demographic information consisting of gender, age, marital status, position, profession and years of service to the institution/department. The interview schedules had an additional five sections each representing an objective of the study.

\subsection{Data Analysis Techniques}

In this study, descriptive analysis of data was employed. It involved the use of measures of central tendencies i.e. mean, measures of dispersion such as standard deviation, and variance to describe a group of subjects (Jupp, 2007). These were used because this study will not generalize the findings beyond the CCIs studied in Kisumu Municipality.

The variables examined in this study were established from the research objectives. The refined data was analyzed using descriptive statistics involving percentages to determine concentrations. Statistical Package for the Social Sciences (SPSS) statistical software was used to analyze the quantitative data. Quantitative data was summarized and categorized according to common themes (Singh, 2007).

\section{Discussion}

\subsection{Questionnaire Return Rate}

A 100\% response return rate was achieved in this study. All the 17 managers of registered CCIs completed and returned the questionnaires. As for the child respondents, 170 children who were selected randomly from the CCIs also completed their questionnaires and returned them. This was achieved because the researcher ensured that the questionnaires were administered and collected immediately after completion. An interview with the children's officer in Kisumu was also done successfully and her views were also collected immediately. The response return rate realized in this study of $100 \%$ is in agreement with Nachmias and Nachmias (1996) who assert that a response return rate of $75 \%$ is adequate for a social research to continue.

\subsection{Care and Protection of Children in a Charitable Children's Institution}

This study sought to examine the extent to which child care in a charitable children's institution influence their safety in Kisumu Municipality. The results were as shown in the tables below; 
Table 4.1. Number of times child beneficiary eat in a day

\begin{tabular}{lll}
\hline The number of times & Frequency (f) & Percentage (\%) \\
\hline 4 & 36 & 21.18 \\
3 & 127 & 74.71 \\
2 & 7 & 4.12 \\
TOTAL & 170 & 100.00 \\
\hline
\end{tabular}

According to table 4.1 above, $36(21.18 \%)$ of child respondents in CCIs eat 4 meals per day while another 127 (74.71\%) eat 3 meals per day. This means that the majority of children in CCIs in Kisumu Municipality have at least 3 meals per day. Only $7(4.12 \%)$ of the child respondents indicated that they have 2 meals per day. As far as nutrition is concerned, it was observed that most CCIs in Kisumu Municipality are able to provide the children with meals at least three times a day thus showing that children in CCIs are in relative safety as far as food is concerned. Obvious cases of malnutrition were not observed in the CCIs visited.

It was important to establish the last time the respondents felt sick in order to ascertain whether sickness in the CCIs is a frequent occurrence or not. Table 4.2 below show the responses on the question, 'the last time the children fell sick?'

Table 4.2. Last time beneficiary was sick

\begin{tabular}{lll}
\hline Last time beneficiary was sick & Frequency (f) & Percentage (\%) \\
\hline Over 1 Year Ago & 58 & 34.12 \\
6 Months - 1 Year Ago & 16 & 9.41 \\
3 Months - 6 Months Ago & 27 & 15.88 \\
1 Month - 3 Months Ago & 21 & 12.35 \\
Less Than 1 Month Ago & 48 & 28.24 \\
TOTAL & 170 & 100.00 \\
\hline
\end{tabular}

Out of the 170 child respondents on the question the last time they were sick, only $58(34.12 \%)$ were sick for the last time over one year ago, while the rest were sick at least less than one year ago. These indicate that sickness in CCIs is a frequent occurrence. It therefore means that for the safety of the children in the CCIs to be good in terms of their health, there is need for an efficient and reliable mechanism to ensure treatment for the children.

There was need to establish whether the respondents were treated so that to demonstrate whether the CCIs are treating the children when they fall sick. This also shows the commitment of the CCIs on the health issues of the children they are caring for. Table 4.3 below gives a summary of the findings on whether the children were treated the last time they fell sick.

Table 4.3. Responses on whether beneficiaries were treated or not treated

\begin{tabular}{lll}
\hline Treated or not treated & Frequency (f) & Percentage (\%) \\
\hline Yes & 146 & 85.88 \\
No & 24 & 14.12 \\
TOTAL & 170 & 100.00 \\
\hline
\end{tabular}

Table 4.3 above shows that $146(85.88 \%)$ of children in CCIs are treated whenever they fall sick. This means that CCIs has a positive influence on the safety of the children living in them in terms of health care. It however cannot go unnoticed that $24(14.12 \%)$ of the sick children were not treated. This can compromise the safety of the children as simple and treatable conditions can turn complicated and put the lives of the children at risk. Contagious diseases can also spread and cause harm to other children if they are not treated at the earliest opportunity.

The study sought to find out if there were health and nutrition programs that the CCIs were running for the children. These programs were a means of ensuring that the health and nutrition of the children were monitored for the purposes of their good care. The responses are summarized in table 4.4 below.

Table 4.4. CCIs with health and nutrition programs

\begin{tabular}{lll}
\hline $\begin{array}{l}\text { Any program that ensures that health and } \\
\text { nutrition of children are taken care of }\end{array}$ & Freq & Perc (\%) \\
\hline Yes & 14 & 82.35 \\
No & 3 & 17.65 \\
Total & 17 & 100.00 \\
\hline
\end{tabular}

Table 4.4 above shows that out of 17 CCIs managers, 14 of them indicated that they have health and nutrition program for their children while 3 CCIs did not have any programs in place. This means that the children in the 3 CCIs that lack health and nutrition programs were at greater risk on health and nutrition. This further poses a danger on their health and compromises on their safety. However the majority of the CCIs had health and nutrition programs thus enhancing the safety of the children.

The respondents opinions were sought on whether they think their institutions are taking care of all the psychosocial needs of the children they serve. The responses of the managers are summarized in table 4.5 below.

Table 4.5. Psychosocial Needs of all children served.

\begin{tabular}{lll}
\hline $\begin{array}{l}\text { In your opinion, do you think this institution } \\
\text { takes care of all the psychosocial needs of all } \\
\text { the children it serves? }\end{array}$ & Freq & Perc \\
\hline Yes & 9 & 52.94 \\
No & 3 & 17.65 \\
Some & 5 & 29.41 \\
Total & 17 & 100.00 \\
\hline
\end{tabular}

According to table 4.5 above, out of 17 CCIs managers 9 $(52.94 \%)$ of the managers indicated that their institutions are taking care of all psychosocial needs of all the children they serve. Another 5 managers indicated that some psychosocial needs are met while $3(17.65 \%)$ managers indicated that the psychosocial needs of children are not met. This means that a substantial proportion of children in CCIs in Kisumu municipality are in need of psychosocial support. Failure to provide this kind of support may compromise the safety of the children in the CCIs because the children may fall prey to vices such us drug and substance abuse as they seek to find solace (SOS, 2007).

This question sought to find out whether children were ready or prepared for disaster such as fire. This is because in Defining Safetythe child is either safe or unsafe now (Corey and Holder, 1985). The responses of the children on this question were as in table 4.6 below. 
Table 4.6. Knowledge of what to do in case of emergency

\begin{tabular}{lll}
\hline $\begin{array}{l}\text { Knowledge of what to do in case of } \\
\text { emergency }\end{array}$ & Freq (f) & Perc (\%) \\
\hline Non Response & 5 & 2.94 \\
Yes & 128 & 75.29 \\
No & 37 & 21.76 \\
TOTAL & 170 & 100.00 \\
\hline
\end{tabular}

According to table 4.6 above, out of 170 children, 128 $(75.29 \%)$ of them indicated that they have some knowledge on what to do in case of an emergency like fire. This indicates that the majority of the children have knowledge of what to do but the question that remains is a child is either safe or unsafe. Emergencies like fire breakout may cause disaster if the level of preparedness is low (Bose, 2006).

This study also set to find out whether the managers of the CCIs had a disaster response plan in place. The responses of the managers on this question are summarized in table 4.7 below.

Table 4.7. Response on disaster response plan

\begin{tabular}{lll}
\hline Do you have a disaster response plan? & Frequency & Percentage \\
\hline Yes & 5 & 29.41 \\
No & 12 & 70.59 \\
Total & 17 & 100.00 \\
\hline
\end{tabular}

According to table 4.7 above, 12 (70.59\%) managers indicated that they did not have any disaster response plan. This means that in case of a disaster the response will be on ad hoc basis with no proper coordination. This can cause increase in injury and fatalities to the children and the people working in the CCIs. The children are therefore living in unsafe environments in CCIs in Kisumu Municipality.

To establish whether child abuse cases happen and are being reported to the management for the CCI. Questions were formulated and results were as shown in Table 4.8 below.

Table 4.8. If Cases of child abuse.

\begin{tabular}{lll}
\hline Have you had case/s of child abuse in this CCI? & Freq & Perc \\
\hline Yes & 5 & 29.41 \\
No & 12 & 70.59 \\
Total & 17 & 100.00 \\
\hline
\end{tabular}

According to table 4.8 out of 17 CCIs managers interviewed, $5(29.41 \%)$ indicated that they have recorded cases of child abuse within their institutions while 12 (70.59\%) CCIs do not have reported cases of child abuse. This means that reported cases of child abuse exist in CCIs where none should actually exist. This is a serious situation because there could be some cases that are not reported thus showing a higher frequency of child abuse cases in CCIs of Kisumu Municipality.

\subsection{Staff Competencies in Charitable Children's Institutions}

This study investigated the staff competencies in charitable children's institutions influence child safety in Kisumu Municipality. The children's responses whether services offered by staff in CCIs are good are summarized in table 4.9 below.
Table 4.9. Response on services offered by staff in CCIs is good

\begin{tabular}{llll}
\hline Staff competencies & YES & NO & n/a \\
\cline { 2 - 4 } & $(\mathbf{f})(\mathbf{\%})$ & $(\mathbf{f})(\mathbf{\%})$ & $(\mathbf{f})(\%)$ \\
\hline $\begin{array}{l}\text { Do the caregivers offer good } \\
\text { services to you? }\end{array}$ & $121(71.18)$ & $49(28.82)$ & $0(0.00)$ \\
$\begin{array}{l}\text { Do the social workers offer } \\
\text { good services to you? }\end{array}$ & $112(65.88)$ & $24(14.12)$ & $34(20.00)$ \\
$\begin{array}{l}\text { Do the cooks make good } \\
\text { food? }\end{array}$ & $162(97.06)$ & $8(2.94)$ & $0(0.00)$ \\
$\begin{array}{l}\text { Do the cleaners and grounds } \\
\text { men do a good job? }\end{array}$ & $15(8.82)$ & $155(91.18)$ & $0(0.00)$ \\
$\begin{array}{l}\text { Does the office offer you } \\
\text { good services? }\end{array}$ & $152(89.41)$ & $7(4.12)$ & $11(6.47)$ \\
\hline
\end{tabular}

According to table 4.9 above, out of 170 children, 121 $(71.18 \%)$ of them indicated that the caregivers in the CCIs are offering them good services. $112(65.88 \%)$ of the children indicated that the social workers offer them good services and $162(97.06 \%)$ of the children indicated that the cooks make good food. These three responses show that the children are happy to a greater extent to the services that they receive from these three categories of staff in their respective CCIs. These responses imply that the children's wellbeing in CCIs is enhanced and so is their safety. It is however notable that only $15(8.82 \%)$ of the children in the CCIs think that the cleaners are doing a good job while the rest are not. Cleaning is a very important function in CCIs because it affects the health of the children directly. The safe environment of children is compromised by the fact that the majority of the children in the CCIs think that the cleaners are not doing a good job. Majority of the children in the CCIs i.e. 152 (89.41\%) believe that their respective offices or CCIs administration is offering them good services. This means that the children in the CCIs have most of their issues sorted out through their various administrations. This further implies that the staffs working in these offices are to a wide extent competent enough to respond to the needs of the children.

The study also sought to determine which combinations of skills are available in the CCIs in Kisumu Municipality. This is important because various combinations of skills are necessary for staffs of CCIs to have in order to meet the needs of the children. Table 4.10 below indicates the combinations of skills as responded by the 17 CCIs managers.

Table 4.10. Skills of staff in CCIs

\begin{tabular}{lll}
\hline What skills do your staffs have in this institution? & Freq & Perc \\
\hline $\begin{array}{l}\text { Administrators, housekeepers, teachers, counselors } \\
\text { Administrators, social worker, cooks, housekeepers, } \\
\text { counsellors }\end{array}$ & 3 & 17.65 \\
$\begin{array}{l}\text { Administrators, social worker, cooks, counsellors, } \\
\text { maintenance, security }\end{array}$ & 7 & 41.18 \\
$\begin{array}{l}\text { Administrators, social worker, nurse, cooks, } \\
\text { housekeepers, maintenance, security } \\
\begin{array}{l}\text { Administrators, social workers, nurse, cooks, } \\
\text { housekeepers, teachers, counsellors, maintenance, }\end{array}\end{array}$ & 2 & 11.76 \\
$\begin{array}{l}\text { security } \\
\text { Total }\end{array}$ & 1 & 5.88 \\
\hline
\end{tabular}

According to table 4.10 above, managers of most CCIs indicated that their CCIs had a combination of professionals within their institutions. However some CCIs lacked some 
professionals that are vital to the CCIs. Table 10 shows the combination of skills in CCIs in Kisumu Municipality. From this table it is clear that some staffs in the CCIs are doubling in their responsibilities. For example $3(17.65 \%)$ of CCIs indicated that they do not have cooks while all the children in those CCIs indicated that they eat and no CCI indicated that the children cook.

\section{Conclusions and Recommendations}

\subsection{Conclusions}

The purpose of this study was to determine the influence of human factors in charitable children's institution on child safety in Kisumu Municipality. Results of this study indicate that human factors child care in CCIs in Kisumu Municipality have some influence on child safety. Child care and protection is shaped by various factors in Kisumu Municipality. These include nutrition, health, child rights, psychosocial needs and disaster preparedness. These are key components to the wellbeing of children and ultimately to their safety. It can be concluded that most CCIs in Kisumu Municipality are to a greater extent addressing nutritional needs of their children. This however must include the qualitative aspect of the meals i.e. balanced diet for it to be complete. As far as health is concerned, more still needs to be done by most CCIs. Timely treatment of all the children when they are sick is very important. This will not only cure the sickness but also boost the health of all the children in the CCIs. Good health is a key component to the safety of the children.

The rights of the children in the CCIs must always be upheld. The children should be encouraged to participate more on issues that affect them. Not all CCIs in Kisumu Municipality are upholding the rights of the children they take care of and thus compromising the safety of the children. The psychosocial needs of the children should also be addressed together with these other needs. Some children are predisposed to unsafe environment of isolation, loneliness, lack of a sense of belonging and others may fall prey to vices such us drug and substance abuse because the CCIs are not offering enough opportunities for psychosocial activities such as clubs for the children. The children should also be taught on how to respond on emergency situation in more practical ways to enhance their disaster preparedness in order to ensure their safety.

Lastly, the competencies of staff in CCIs, is very important to ensure the safety of the children in Kisumu municipality. CCIs in Kisumu Municipality are not properly equipped with professional staff in all areas of service. It is clear that some staffs in the CCIs are doubling in their responsibilities. This doubling of responsibility has negative influence on the child's safety. Adequate, competent and experienced staffs are a prerequisite for ensuring child safety.

\subsection{Recommendations}

In order for CCIs to take good care and protect their beneficiaries, they must provide a complete package of essential services to them. Nutrition should be provided in sufficient quantities, frequency and quality. The diet must be balanced at all time. All the children should be screened and treated for all diseases. Psychosocial needs of the children should be addressed by providing opportunities for quality interaction among the children and with professional children workers. CCIs should have disaster preparedness plan that include practical drills with the children. Competent and experienced staffs are a prerequisite for CCIs to deliver safety for their child beneficiaries. Similarly, all CCIs must have a combination of skilled and professional staffs that are qualified in the work they do. There should be no doubling of responsibilities by staff to ensure productivity and quality service to the children. The following areas may needed further research. The role of electronic communication systems on child safety in CCIs, the role of Area advisory councils and children's department in ensuring the safety of children in CCIs and governance and accountability in CCIs.

\section{References}

[1] Action Aid (2007) Children's Act 2001 and UNCRC, popular version, Kenya Alliance for advancement of children.

[2] ANPPCAN. (1995) Hearing on street children in Kenya, Report on hearing held in Nairobi, 4 and 5 November 1994

[3] Biemba G. et al. (2009) Kenya Research Situation Analysis on Orphans and Other Vulnerable Children, Boston University Center for Global Health, and Development, Massachusetts in collaboration with University of Nairobi Institute for Development Studies. Nairobi, Kenya

[4] Bose (2006)Modern Encyclopedia of Disaster and Hazard Management, Rajat Publications, New Delhi, India

[5] Care Reform Initiative (2008), Orphans and Vulnerable Children. Retrieved from the website of CRI Ghana http://www.ovcghana.org/index.html 14th Feb 2011 at 10:55 p.m.

[6] Catron C. (2006), Dreams of Kisumu http://www.worldpress.org/Africa/2497.cfm 14th Feb 2011 at 10:35 p.m.

[7] Centre for Sharing (2007) KisumuSLSReport Retrieved from the website of centre for sharing http://www.centerforsharing.org/KisumuSLSReport2 07.htm 12th Feb 2011 at 11:35 a.m.

[8] Clerical Whispers (2009) Church on the defensive over Father Kizito saga: Retrieved from the website of Clerical Whispers no $5^{\text {th }} \quad$ March 2011 at 1:03 p.m. http://clericalwhispers.blogspot.com/2009/06/churchn-defensive-over-father-kizito.html

[9] Cole G., (2004) Management Theory and Practice, BookPower/ELST $6^{\text {th }}$ Edition, London, England

[10] Cotton A. (2008) protection policy, Retrieved from the website of Social edge in Feb 2011 http://www.socialedge.org/discussions/responsibility/ hild-protection-policy 14th Feb 2011 at 8:20 p.m.

[11] Cox B. C. and Marks J., (2007) This Immoral Trade, Slavery in the $21^{\text {st }}$ Century, WorldAlive Publishers LTD. Nairobi, Kenya. 
[12] DCF, (2002)Children's Homes or Similar Institutions, Residential Treatment Facilities, Group Homes, and Temporary Shelters. Retrieved from the website of DFC At http://www.ct.gov/dcf/cwp/view.asp?a=2639\&Q $=32878$ on $4^{\text {th }}$ March 2011 at 2:33 p.m.

[13] Ennew, J. 1994. Street and working children: a guide to planning development (Manual 4) London: Save the children.

[14] Gary D., (2008).Human Resource Management, $2^{\text {nd }}$ edition. Prentice Hall of India, New Delhi, India.

[15] Gilbert, D. (1998). The American class structure: In an age of growing inequality. Belmont, CA: Wadsworth Press

[16] GOK, (2005) Guidelines and checklist for inspection of Charitable Children's Institutions.

[17] GOK, (2011).Children and Social Development. Ministry of Gender

[18] Hooghiemstra P., Amsterdam sex abuser worked in Kenya orphanagePublished on: 15 December 2010 - 5:46pm, Radio Netherlands world

[19] Jupp V. (2006) The Sage Dictionary of Social Research Methods, Sage publications Itd. London, England

[20] Kirk, J., \& Miller, M. L. (1986).Reliability and validity in qualitative research. Beverly Hills: Sage Publications.

[21] Kothari C. R. (2004) Research Methodology, Methods and techniques, $2^{\text {nd }}$ edition, New age techo press, New Delhi

[22] Lusk, M.W. (1989) "Street Children Program in Latin America". In: The journal of Sociology and social welfare, 16(1), March

[23] Maslow A.H., (1943) Atheory of Human Motivation, Psychological Review,

[24] Microsoft Corporation (2005) Care and Protection, Microsoft Encarta Premium Suite.

[25] Mushenga(1976)Crime and Deviance, an introduction to criminology, East African Literature Bureau, Nairobi, Kenya.

[26] Nachmias C. F. and Nachmias D, (2005) Research Methods in the Social Sciences, $5^{\text {th }}$ Edition, Arnold, London.

[27] Osemwegie, Adesuwe. (1998) Street Children in Lagos. UNDP/UNCHS/World Bank Urban Management Programme Regional Office for Africa.

[28] Osoo W. Y. and Onen D.A (2005) General Guide to Writing Research Proposal and Report. Options press. Kisumu, Kenya.

[29] Ouma G. W. (2004) Education for street children in Kenya: the role of the Undugu Society. International institute of education planning, Paris.

[30] Peter, C.B, (1994) A giude to Academic Writing, A.M.C.E.A

[31] Gaba Publications, Eldoret-Kenya

[32] Prewitt, (1975) Introductory Research Methodology, East African Application, Institute of Development Studies, University of Nairobi, Kenya.

[33] Rukwaru M. (2007) Fundamentals of Social Research Eureka Publishers, Meru Kenya.

[34] Sapsford R. (2007) Survey Research, Sage Publication LTD, London, England
[35] Shanghai Star, (2001) Ramadan brings charity to Egypt's orphans $(12 / 13 / 2001)$.

[36] Singh K. (2007) Quantitative Social Research Method, Sage publications LTD. London England

[37] Smet P. (2010), Massive child abuse at Amsterdam day care centersPublished on: 13 December 2010 - 12:42pm, Radio Netherlands world wide

[38] SOS (2007) Family Strengthening ProgramToolkit for region of Southern Africa II

[39] Stanfield and Bwibo, (2005) Child Health $3^{\text {rd }}$ Edition, The African Medical and Research foundation, Nairobi, Kenya

[40] Suda C. A. (2001) The Invisible Child Worker in Kenya: The Intersection of Poverty, Legislation and Culture. Nordic Journal of African Studies 10(2): 163-175

[41] UNICEF (2001) Profiting from Abuse, an investigation into sexual exploitation of our children, New York, USA.

[42] UNICEF (2005) Early Marriage, a harmful traditional practice, New York, USA.

[43] UN HABITAT (2005) Kenya slum upgrading program, Situational analysis for informal land settlements in Kisumu, Kenya.

[44] UNEP, (2007) Competencies Retrieved from the website of UNEP February http://www.unep.org/vacancies/PDF/competencies.pdf 14th Feb 2011 at 1:02 p.m.

[45] Price, A. (2011). Human Resource Management. New York, Cengage Learning.

[46] Rhoades, L., Eisenberger, R.,\&Armeli, S.(2001). Affective Commitment to the Organization: The Contribution of Perceived Organizational Support. Journal of Applied Psychology, 86(5), 825-836.

[47] Sultana, A., Irum, S., Ahmed, K., \&Mehmood, N.(2012). Impact of Training on Employee Performance: A Study of Telecommunication Sector in Pakistan, Interdisplinary. Journal of Contemporary Research in Business, 4(6), 646-661.

[48] Lee, W. (2010). The Relationship between Job Characteristics and Job Satisfaction Toward Affective Commitment; The Case of Engineers in SepakatSetiaPerunding SDN BHD. Unpublished MBA Project, University Sains Malaysia.

[49] Coetzee, M. (2005). The Fairness of Affirmative Action: An Organizational Justice Perspective. Unpublished PHD Thesis, University of Pretoria.

[50] Beck, K., \& Wilson, C. (2000). Development of affective organizational commitment: A crosssequential examination of change with tenure. Journal of Vocational Behavior, 56(1), 114-136.

[51] Mahony, D., Klimshak, M., \& Morrell, D.(2012). The Portability of Career-Long Experience: Propensity to Trust as a Substitute for valuable Work Experience. Career Development International, 17(7), 606-625.

[52] Condrey, S.(2010). Handbook of Human Resources Management.Oxon, John Wiley \& Sons.

[53] Armstrong, M., \&Murlis, H. (2007).Reward Management: A Handbook of Remuneration Strategy and Practice. London, Kogan Page Limited. 
[54] Amany. (1999) Other families, Al-Ahram Weekly (5/1999).

[55] Action for Child Protection (May 2008). A Brief History of Child Safety Intervention Retrieved August 2008 from Action for Child Protection web site. http://www.actionchildprotection.org/PDF/
[56] Free Dictionary (2010). Playing field. Retrieved February 2011 from free dictionary website http://encyclopedia.thefreedictionary.com/playing+field $14^{\text {th }}$ Feb 2011

[57] Réhab E., (11/2002).A Child by Any Other Name.Egypt Today (11/2002). 